\title{
Порушення жовчоутворювальної функції печінки на тлі гострої виразки шлунка та їх корекція тіотриазоліном в експерименті
}

\author{
R. I. TSYTSIURA \\ SHEI "Ternopil State Medical University by I. Ya. Horbachevsky"
}

\section{VIOLATION OF BILIGENIC LIVER FUNCTION ON THE BACKGROUND OF AN ACUTE PEPTIC ULCER AND THEIR CORRECTION BY THIOTRIAZOLINE IN THE EXPERIMENT}

\begin{abstract}
Моделювання гострої виразки шлунка через 7 діб супроводжується порушенням жовчоутворювальної функції печінки, що проявляється суттєвим зниженням вмісту в жовчі загальних жовчних кислот, прямого білірубіну та ступеня його кон'югації. Застосування тіотриазоліну впродовж семи днів після моделювання гострої виразки шлунка в дозі 9,07 мг на кілограм маси тварини внутрішньоочеревинно супроводжується вираженим гепатопротекторним ефектом, який проявляється нормалізацією досліджуваних показників жовчоутворювальної функції печінки.

Modeling of an acute gastric ulcer in 7 days is accompanied by violation of biligenic liver function, manifested in a significant reduction of the common bile acids, direct bilirubin and degree of its conjugation. Application of Thiotriazoline within seven days after modeling of an acute gastric ulcer at a dose of $\mathbf{9 . 0 7}$ milligram per kilogram of an animal's body weight intraperitoneally is accompanied by a pronounced hepatoprotective effect, which manifests in normalization of parameters of studied biligenic liver function.
\end{abstract}

Постановка проблеми і аналіз останніх досліджень та публікацій. Анатомо-фізіологічний взаємозв’язок шлунка і ДПК з печінкою, їх функціональна взаємодія, відносна спільність кровопостачання i нейрогуморальної регуляції зумовлюють високу частоту патології гепатобіліарної зони тлі ураження шлунка [8]. Так, за даними [1], у більш ніж половини хворих на пептичну виразку дванадцятипалої кишки з тривалістю захворювання від 10 до 32 років відмічаються явища холецистопанкреатиту. За даними [2], у 59,2 \% хворих на пептичну виразку виявлено ультразвукові ознаки хронічного холециститу, у 34,6 \% - дискінезію жовчовивідних шляхів за гіпотонічним типом, у 7,7 \% - жовчнокам'яну хворобу. У 20 \% пацієнтів відмічали зміну паренхіми печінки. Констатували, що в міру зростання частоти рецидивів прогресують і морфофункціональні зміни гепатобіліарної системи [9].

Однак, основні ланки патогенезу супутнього ураження печінки та його профілактики на тлі гострої виразки шлунка не досліджено.

Мета роботи: 3'ясувати особливості порушень жовчоутворювальної функції печінки на тлі експериментальної гострої виразки шлунка та ефективність їх профілактики тіотриазоліном.
Матеріали і методи. Експерименти проведено на 30 білих статевозрілих нелінійних щурахсамцях масою тіла 170-180 г, яких утримували на стандартному раціоні віварію. Дослідження проводили відповідно до Європейської конвенції з захисту лабораторних тварин [7] та ухвали Першого національного конгресу з біоетики (Київ, 2000). Тварин поділили на три групи: I - контрольна, якій в умовах тіопентало-натрієвого знеболювання (40 мг на кілограм маси) з дотриманням правил асептики й антисептики виконували серединну лапаротомію й через 10 хв рану пошарово зашивали. Через 1 добу впродовж семи днів внутрішньоочеревинно вводили фізіологічний розчин в еквівалентному об’ємі до розчину тіотриазоліну; II - група, в якій після серединної лапаротомії на дванадцятипалу кишку накладали стерильний затискач Пеана на 10 хв для моделювання гострої виразки шлунка [3], після чого рану пошарово зашивали. Через 1 добу впродовж семи днів внутрішньоочеревинно вводили фізіологічний розчин в еквівалентному об’ємі до розчину тіотриазоліну; III - група, в якій після моделювання гострої виразки шлунка через 1 добу впродовж семи днів внутрішньоочеревинно вводили 2,5 \% розчин тіотриазоліну (“Артеріум”, Україна) в дозі 9,07 мг на 
кілограм маси тварини, яка відповідала середньодобовій дозі 100 мг для дорослої людини [4]. Препарат вводили одноразово в один і той самий час в першій половині дня.

Жовчовидільну функцію печінки оцінювали на основі методичних рекомендацій з доклінічного вивчення лікарських препаратів [3]. Через одну добу після останнього введення досліджуваних фармакологічних препаратів під тіопенталонатрієвим знеболюванням (80 мг на кілограм маси) у тварин катетеризували загальну жовчну протоку і збирали жовч протягом 1 год. В отриманій жовчі, за методикою Мирошниченко В. П. і співавт. (1978), визначали концентрацію сумарних жовчних кислот і холестеролу, оцінювали літогенні властивості жовчі за холато-холестероловим коефіцієнтом: сумарні жовчні кислоти/холестерол. У жовчі визначали також концентрації загального, прямого і непрямого білірубіну за методом Ван ден Берга в модифікації М. П. Скакуна. Крім цього, обчислювали ступінь кон'югації білірубіну за співвідношенням: прямий білірубін/загальний білірубін (\%).

Отримані цифрові дані піддавали статистичному аналізу. Відмінності між експериментальними групами тварин оцінювали за критерієм Стьюдента.

Результати досліджень та їх обговорення. Як видно з таблиці 1, через 7 діб після моделюван- ня гострої виразки шлунка порівняно із контрольною групою відмічали істотне зниження вмісту в жовчі загальних жовчних кислот (на 14,9 \%, $\mathrm{p}<0,05)$, прямого білірубіну (на 18,0 \%, p<0,05), а також ступеня кон’югації білірубіну (на 19,6 \%, p<0,05). Відмінності щодо вмісту холестеролу, загального і непрямого білірубіну на тлі моделювання гострої виразки шлунка були статистично не вірогідними ( $>0,05)$.

Так само не було істотних відмінностей за величиною холато-холестеролового співвідношення, яке відображає літогенні властивості жовчі [5].

Отримані результати свідчать про те, що під впливом модельованої гострої виразки шлунка виникає порушення жовчоутворювальної функції печінки, що проявляється зниженням утворення загальних жовчних кислот та кон'югації білірубіну. Можна припустити, що в основі виявлених порушень лежить порушення нейрогормональної регуляції процесу утворення жовчі. Оскільки до пулу жовчних кислот, які виділяються із жовчю, входять жовчні кислоти, які надходять із кишок внаслідок кишково-печінкової рециркуляції і повторно захоплюються печінкою, а також ті, які синтезуються наново із холестеролу в мікросомальній системі гепатоцитів [6], можна припустити, що у механізмі зниження вмісту жовчних кислот домінує зниження здатності печінки захоплювати жовчні кислоти із крові, оскільки вміст холестеролу майже не змінюється. В умовах гострої виразки шлунка знижу-

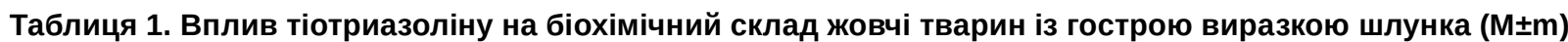

\begin{tabular}{|c|c|c|c|}
\hline Показник & $\begin{array}{c}\text { I група } \\
\text { Контроль } \\
(\mathrm{n}=10)\end{array}$ & $\begin{array}{c}\text { II група } \\
\text { Виразка шлунка } \\
(\mathrm{n}=10)\end{array}$ & $\begin{array}{c}\text { III група } \\
\text { Виразка шлунка + тіотриазолін } \\
(\mathrm{n}=10)\end{array}$ \\
\hline Загальні жовчні кислоти, г ${ }^{-1}$ & $3,350 \pm 0,132$ & $2,850 \pm 0,201^{*}$ & $\begin{array}{c}3,332 \pm 0,078 \\
p<0,05\end{array}$ \\
\hline Холестерол, г• $\pi^{-1}$ & $0,259 \pm 0,018$ & $0,230 \pm 0,026$ & $\begin{array}{c}0,238 \pm 0,022 \\
p>0,05\end{array}$ \\
\hline Холато-холестероловий коефіцієнт & $13,3 \pm 1,2$ & $13,4 \pm 1,9$ & $\begin{array}{c}14,0 \pm 1,2 \\
\mathrm{p}>0,05\end{array}$ \\
\hline Загальний білірубін, мкмоль ${ }^{-1}$ & $96,9 \pm 5,6$ & $91,2 \pm 3,4$ & $\begin{array}{c}93,1 \pm 3,7 \\
\mathrm{p}>0,05\end{array}$ \\
\hline Прямий білірубін, мкмоль ${ }^{-1}{ }^{-1}$ & $57,7 \pm 3,4$ & $47,3 \pm 1,8^{*}$ & $\begin{array}{c}54,1 \pm 2,2 \\
\mathrm{p}<0,05\end{array}$ \\
\hline Непрямий білірубін, мкмоль ${ }^{-1}{ }^{-1}$ & $39,9 \pm 4,0$ & $43,9 \pm 3,4$ & $\begin{array}{c}41,0 \pm 3,5 \\
p>0,05\end{array}$ \\
\hline Ступінь кон’югації білірубіну, \% & $59,8 \pm 1,2$ & $48,1 \pm 1,4^{*}$ & $\begin{array}{c}58,1 \pm 2,9 \\
\mathrm{p}<0,05\end{array}$ \\
\hline
\end{tabular}

Примітка. ${ }^{*}$ - відмінності стосовно контрольної групи статистично вірогідні (p<0,05); p - вірогідність відмінностей між I і II дослідними групами. 
ється вміст у жовчі прямого білірубіну. Цей факт підтверджує порушення функції мембран як ендоплазматичного ретикулуму, так і комплексу Гольджі, де відбувається кон'югація білірубіну з глюкуроновою кислотою.

Застосування тіотриазоліну супроводжувалося вираженим гепатопротекторним впливом. Усі досліджувані показники до 8-ї доби експерименту перебували на рівні контрольної групи. Порівняно з тваринами без корекції статистично вірогідно збільшувався вміст у жовчі загальних жовчних кислот (на 16,9 \%, р $<0,05)$, прямого білірубіну (на $14,4 \%, \mathrm{p}<0,05$ ) та ступеня його кон'югації (на $20,8 \%, p<0,05)$. Враховуючи той факт, що в основі механізму дії тіотриазоліну лежить стабілізація клітинних мембран, стає очевидним, що в умовах гострої виразки шлунка насамперед виникають порушення мембранозалежних процесів, до яких належить захоплення із крові жовчних кис-

\section{СПИСОК ЛІТЕРАТУРИ}

1. Авраменко А. А. Влияние длительности обострения язвенной болезни двенадцатиперстной кишки на сроки формирования реактивного холецистопанкреатита / А. А. Авраменко, А. И. Гоженко, Р. Н. Короленко // Клінічна та експериментальна патологія. - 2003. - Т. 2, № 1. - С. 2-4.

2. Вахрушев Я. М. Исследование функционального состояния гепатобилиарной системы в динамике лечения больных язвенной болезнью / Я. М. Вахрушев, И. В. Муфаздалова // Экспериментальная клиническая гастроэнтерология. - 2005. - № 2. - C. 44-48.

3. Доклінічні дослідження лікарських засобів : метод. рекоменд. ; за ред. чл.-кор. АМН України О. В. Стефанова. - К. : Авіценна, 2001. - 528 с.

4. Клиническое применение тиотриазолина в терапии / И. А. Мазур, Н. А. Волошин, И. С. Чекман [та ін.] // Сучасна гастроентерологія. - 2006. - № 1. - С. 71-74. лот, кон’югація білірубіну та їх виділення у жовчних капілярах.

Таким чином, тіотриазолін $є$ перспективним засобом протекції супутнього ураження печінки на тлі гострої виразки шлунка.

Висновки. 1. Моделювання гострої виразки шлунка через 7 діб супроводжується порушенням жовчоутворювальної функції печінки, що проявляється суттєвим зниженням вмісту в жовчі загальних жовчних кислот, прямого білірубіну та ступеня його кон'югації.

2. Застосування тіотриазоліну впродовж семи днів після моделювання гострої виразки шлунка в дозі 9,07 мг на кілограм маси тварини внутрішньоочеревинно супроводжується вираженим гепатопротекторним ефектом, який проявляється нормалізацією досліджуваних показників жовчоутворювальної функції печінки.

5. Методические рекомендации по экспериментальному изучению желчегонной, холеспазмолитической, холелитиазной и гепатопротекторной активности новых лекарственных веществ / С. М. Дроговоз, С. И. Сальникова, Н. П. Скакун, В. В. Слышков. - К. : ФКМЗ Украины, 1994. - 46 с.

6. Чекман И. С. Микросомальная ферментная система организма / И. С. Чекман, К. А. Посохова, Е. Г. Береговая. - К., 1996. -80 c.

7. Europen convention for the protection of vertebrate animals used for experimental and other scientific purposes. - Strasbourg : Council of Europe, 1986. - 1986. - № 123. - P. 52.

8. Manes G. Helicobacter pylori and pancreatic disease / G. Manes, A. Balzano, D. Vaira // J. Pancreas. - 2003. - Vol. 4, № 3. - P. 111-116.

9. Saad R. J. Peptic ulcer disease in patients with chronic liver disease: looking beyond bugs and drugs / R. J. Saad, W. D. Chey // Gastrointest. Endosc. - 2005. - Vol. 62, № 3. - P. 357-359.

Отримано 14.07.15 